\title{
N-Alpha-Acetyltransferase 10, NatA Catalytic Subunit
}

National Cancer Institute

\section{Source}

National Cancer Institute. N-Alpha-Acetyltransferase 10, NatA Catalytic Subunit. NCI

Thesaurus. Code 195852.

$\mathrm{N}$-alpha-acetyltransferase $10, \mathrm{Nat} A$ catalytic subunit (235 aa, $\sim 26 \mathrm{kDa}$ ) is encoded by the human NAA10 gene. This protein is involved in catalyzing the acetylation of protein substrates. 